\title{
Conceptual Design Development of Coal-to-Methanol Process with Carbon Capture and Utilization
}

\author{
Siddig S. Khalafalla ${ }^{1}$, Umer Zahid ${ }^{1, *}$ (D), Abdul Gani Abdul Jameel ${ }^{1}$, Usama Ahmed ${ }^{1}$, \\ Feraih S. Alenazey ${ }^{2}$ and Chul-Jin Lee ${ }^{3, *(D)}$ \\ 1 Chemical Engineering Department, King Fahd University of Petroleum and Minerals, \\ Dhahran 31261, Saudi Arabia; siddig@kfupm.edu.sa (S.S.K.); a.abduljameel@kfupm.edu.sa (A.G.A.J.); \\ usama.ahmed@kfupm.edu.sa (U.A.) \\ 2 King Abdulaziz City for Science and Technology (KACST), Riyadh 11442, Saudi Arabia; \\ alenazey@kacst.edu.sa \\ 3 School of Chemical Engineering and Materials Science, Chung-Ang University, 84 Heukseok-ro, Dongjak-gu, \\ Seoul 06974, Korea \\ * Correspondence: uzahid@kfupm.edu.sa (U.Z.); cjlee@cau.ac.kr (C.-J.L.)
}

Received: 22 October 2020; Accepted: 27 November 2020; Published: 4 December 2020

\begin{abstract}
Methanol is a clean fuel and an important feedstock for the petrochemical industry. Conventionally, the coal-to-methanol process generates a substantial amount of $\mathrm{CO}_{2}$ emissions with a low yield of methanol. In this study, we propose the conceptual design development of coal-to-methanol process using captured $\mathrm{CO}_{2}$ from the gasification plant by implying process intensification. The base case and three alternative designs have been developed using the Aspen Plus to analyze the process performance. The four designs have been compared in terms of their energy consumption, economics, methanol production rate, and carbon emissions while maintaining the gasifier operation conditions, sulfur content in the syngas, and stoichiometric number at the methanol synthesis reactor. Among the developed designs, the most feasible design requires an energy requirement and product cost of $21.9 \mathrm{GJ}$ and $\$ 142.5$ per ton of methanol product. The study also showed that the coal-to-methanol process assisted with external hydrogen from electrolysis plant for achieving higher production rates and low $\mathrm{CO}_{2}$ emissions is currently not economical due to the high $\mathrm{H}_{2}$ cost.
\end{abstract}

Keywords: methanol; carbon capture and utilization; coal gasification; economic analysis; process simulation

\section{Introduction}

Despite significant advancements and commercialization of the renewable energy, fossil fuel remains the major contributor in the global energy share. Meanwhile, the impact of climate change and rising carbon emissions are serious concerns that need to be responded quickly. Intergovernmental Panel on Climate Change (IPCC) and other global agencies have warned that if not enough action is taken rapidly, the climate change will bring extensive droughts and famines, spread of diseases and displacement of populations [1]. Carbon capture, utilization, and storage (CCUS) is a potential technology that can help with the reduction of $\mathrm{CO}_{2}$ emissions. The conversion of $\mathrm{CO}_{2}$ to valuable chemicals offer cleaner environment as well as an economic advantage. Among many options, $\mathrm{CO}_{2}$ conversion to methanol is one of the key routes and is important feedstock for the downstream production of many other valuable chemicals. Due to its clean combustion characteristics, many countries are promoting methanol blending with the gasoline for its usage in the vehicles. Methanol is also gaining fast acceptance as a marine fuel because of its low emissions compared to the 
heavy fuel oil [2]. In addition, methanol has a wide range of applications including biodiesel production, as a solvent in paints and resins, as an antifreeze agent, and in denitrification of wastewater $[3,4]$. Methanol has an ever-increasing strong market demand and its market increased with a compound annual growth rate (CAGR) of $6 \%$ from 2013 to 2018 and is forecasted to increase with a growth rate of $5 \%$ in the next four years mainly led by methanol-to-olefins (MTO) [5]. Currently, China is the largest consumer of global methanol production, accounting for around $58 \%$ of the methanol usage [5].

Currently, most of the methanol is produced by the catalytic reaction of synthesis gas as shown in Equation (1). Synthesis gas is mainly a mixture of gases containing $\mathrm{H}_{2}, \mathrm{CO}$ and $\mathrm{CO}_{2}$ and is mostly produced through the steam reforming of natural gas [6]. Figure 1 shows the simple process flow diagram for the methanol production from the reforming of natural gas.

$$
\mathrm{CO}+2 \mathrm{H}_{2} \leftrightarrow \mathrm{CH}_{3} \mathrm{OH} \quad \Delta \mathrm{H}=-90.64 \mathrm{~kJ} / \mathrm{mol}
$$

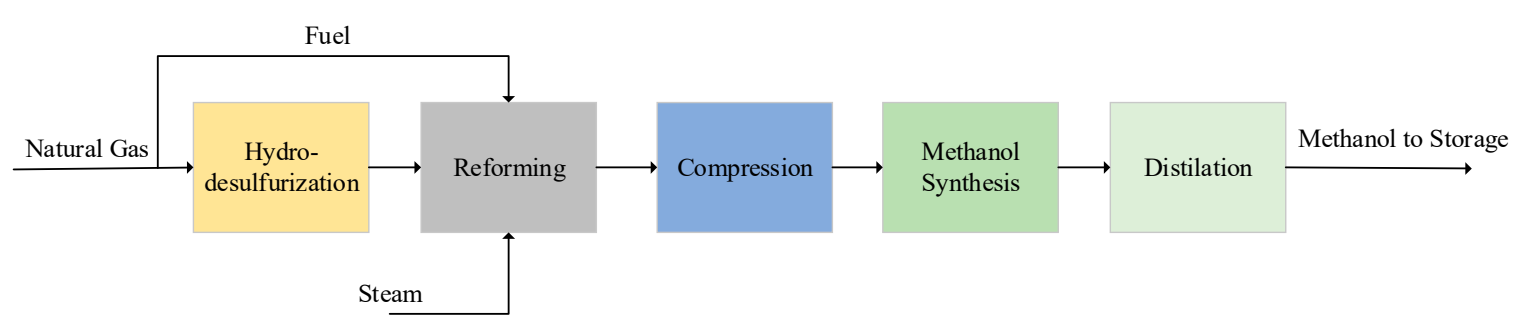

Figure 1. Simplified block flow diagram of the natural gas reforming process for the methanol production.

In recent years, direct hydrogenation of $\mathrm{CO}_{2}$ for methanol production has been a subject of an extensive research due to an alarming level of $\mathrm{CO}_{2}$ in the atmosphere. Many studies have been conducted exploring the thermodynamic, kinetic, catalytic, and process design aspects of $\mathrm{CO}_{2}$ conversion to methanol. Nguyen and Zondervan [7] performed the economic evaluation of $\mathrm{CO}_{2}$ to methanol routes including hydrogenation, bi-reforming, and tri-reforming at three different capacities. Their results showed that bi- and tri-reforming offer $37 \%$ and $39 \%$ lower total annual cost (TAC) respectively compared to the direct $\mathrm{CO}_{2}$ hydrogenation route. Leonzio et al. [8] studied various reactor configurations for $\mathrm{CO}_{2}$ to methanol hydrogenation reaction. They reported the reaction conversion to be $38 \%, 58 \%$ and $69 \%$ for once through reactor, membrane reactor and reactor with recycle respectively. Tamnitra et al. [9] performed the kinetic modelling of methanol synthesis reaction by modifying the work of Setinc and Levec [10] to match the experimental data. Lee et al. [11] proposed an economically optimized design using complex superstructure optimization. The study found that the $\mathrm{CO}_{2}$ conversion can be increased to $52 \%$ using a multistage reactor design with inter-stage product recovery. Xiang et al. [12] proposed the methanol and hydrogen production through chemical looping reforming process by integrating the combustion process to utilize the $\mathrm{CO}_{2}$ emissions. Kim et al. [13] performed the techno-economic evaluation for the poly-generation of methanol, power and heat from the coke oven gas as the feedstock. Similar analysis was performed by Ahmed [14] with the integration of a coal gasification and natural gas reforming process for the methanol production.

Conventionally, the catalyst employed for methanol synthesis is a combination of $\mathrm{Cu} / \mathrm{ZnO} / \mathrm{Al}_{2} \mathrm{O}_{3}$ as reported in the literature. Recently, Agarwal [15] proposed $\mathrm{CO}_{2}$ hydrogenation using metal-organic frameworks (MOFs) for an improved catalytic activity and selectivity of the catalyst. Ting et al. [16] reported the hydrogenation of $\mathrm{CO}_{2}$ to methanol under low reaction temperature condition using $\mathrm{TiO}_{2}$ supported catalysts. Li et al. [17] studied the $\mathrm{CO}_{2}$ hydrogenation $\mathrm{Cu} / \mathrm{AlCeO}$ catalyst and reported that the $\mathrm{Cu} / \mathrm{AlCeO}$ catalyst had the lowest apparent activation barriers for $\mathrm{CO}_{2}$ activation and methanol synthesis.

One of the key economic hurdles in the production of methanol via $\mathrm{CO}_{2}$ hydrogenation is the source of $\mathrm{H}_{2}$. The production of $\mathrm{H}_{2}$ using the conventional reforming processes is energy intensive and contribute to carbon emissions. Some studies have explored the generation of renewable $\mathrm{H}_{2}$ integrated 
with the methanol synthesis process. Van-Dal et al. [18] designed and simulated the conversion of $\mathrm{CO}_{2}$ and $\mathrm{H}_{2}$ to methanol using Aspen Plus. They proposed to capture $\mathrm{CO}_{2}$ from a coal fired power plant and produce $\mathrm{H}_{2}$ from the water electrolysis. Their results showed that 1.6 ton of $\mathrm{CO}_{2}$ can be abated per ton of methanol production. Similarly, Asif et al. [19] studied the methanol production assuming the $\mathrm{H}_{2}$ from the electrolysis unit and $\mathrm{CO}_{2}$ stream from $600 \mathrm{MW}$ supercritical coal power plant using post-combustion chemical solvent based technology. Charoensuppanimit et al. [20] proposed to utilize $\mathrm{H}_{2}$ as a by-product produced from the sodium methoxide $\left(\mathrm{NaOCH}_{3}\right)$ production integrated with methanol synthesis process. A chemical reaction between sodium hydroxide and methanol releases a large amount of $\mathrm{H}_{2}$ that can be utilized to produce back methanol through $\mathrm{CO}_{2}$ hydrogenation. Kiss et al. [21] simulated the methanol synthesis process by $\mathrm{CO}_{2}$ hydrogenation using wet hydrogen by-product from the chlor-alkali production. Chlor-alkali process produces wet $\mathrm{H}_{2}$ as a by-product by performing the salt electrolysis. The energy analysis of this study showed the electricity consumption of $550 \mathrm{kWh}$ and $0.48-1.16$ ton steam per ton methanol produced. Luu et al. [22] studied the dry reforming of $\mathrm{CO}_{2}$ with methane to produce syngas for the methanol production. They evaluated five scenarios for the CCU-methanol system and reported the DMR with additional $\mathrm{H}_{2}$ from carbon-free water splitting plant to be the best case in terms of $\mathrm{CO}_{2}$ emission intensity.

Considering the availability and price fluctuations of the natural gas, alternative feedstocks such as coal and biomass are under investigation to produce syngas. Puig-Gamero et al. [23] simulated the pine gasification process for the production of methanol and performed a sensitivity analysis on some of the variables in the gasification and methanol synthesis section. Liu [24] studied the effect of plant size on the methanol production cost using coal and biomass as the feedstock. The study concluded the coal gasification to be more economical compared to the biomass or biomass-coal feedstocks. Herdem et al. [25] studied the biomass gasification assisted with photovoltaic hydrogen production system for the methanol production under different climatic conditions of Canada and Italy. Rivarolo et al. [26] compared the methanol production from different renewable sources such as solar, wind and hydroelectric to produce renewable $\mathrm{H}_{2}$. Their results showed that there is a great potential for methanol production from renewable sources provided governments provide financial incentives. Wang and Demirel [27] studied the oxy-combustion plant with carbon capture to produce power and methanol through coal gasification. They reported the input energy of $0.56 \mathrm{MW}$ per ton of methanol produced. The study performed a life-cycle assessment to estimate the GHG emissions, water consumption, and energy consumption for coal to methanol process. Similar studies $[28,29]$ have been conducted to analyze the technical and economic aspects of combined power and methanol production process. Gu et al. [30] proposed a coal-based gasification process for the co-production of LNG and methanol. The study performed the energy and economic analysis for the co-production process and reported the IRR to be $19 \%$.

All the existing coal-to-methanol (CTM) plants employ coal gasification to produce syngas. Depending on the coal composition and gasifier technology, the typical syngas ratio $\left(\mathrm{H}_{2}: \mathrm{CO}\right)$ produced from the coal gasification process is in the range of $0.5-0.95$ [31,32] which does not achieve the required stoichiometric ratio as shown in Equation (1). Therefore, the hydrogen amount is increased by reacting the $\mathrm{CO}$ with steam through water gas shift (WGS) to produce additional $\mathrm{CO}_{2}$ which is usually vented to the atmosphere. Similarly, most of the previous studies focusing on CTM process considered the sequestration of $\mathrm{CO}_{2}$ produced from the process and methanol was mainly produced from $\mathrm{CO}$ as shown in Equation (1). This study is focused on the conceptual design of CTM process where the energy intensive carbon capture and WGS units can be removed from the process while utilizing the $\mathrm{CO}_{2}$ for the methanol production. The goal of this work is to propose an improved design for CTM process using process intensification concept whereby minimizing the $\mathrm{CO}_{2}$ emissions from the process. First a base case model is developed by modifying the CTM process reported in literature [33]. Then, three alternative designs have been developed, implying the principles of process intensification to study the feasibility of the proposed designs. Finally, a detailed energy and cost analysis has been performed to ascertain the techno-economic viability of the processes. 


\section{Simulation Methodology}

The general methodology followed in this study comprise of following steps: design conceptualization, process simulation and techno-economic analysis. First, three alternative CTM processes are developed by design intensification of the base case design that can reduce the carbon emissions while maximizing the methanol production. In order to have a fair comparison among various design alternatives, the inlet coal feed rate is fixed for all the cases. In addition, the maximum allowed $\mathrm{H}_{2} \mathrm{~S}$ concentration in the syngas is $100 \mathrm{ppbv}$, while the $\mathrm{CO}_{2}$ removal rate is assumed to be $95 \%$. The stoichiometric number at the inlet of methanol synthesis reactor is maintained at 2 for all the cases. Second, the simulation models have been developed using a commercial tool Aspen Plus. The thermodynamic package employed is the Peng-Robinson with Boston Mathias (PR-BM) equation of state (EOS) as the base method. This property method is recommended for the petrochemical applications where non-polar or mildly polar mixtures of hydrocarbons and light gases, such as $\mathrm{CO}_{2}$, $\mathrm{H}_{2} \mathrm{~S}$, and $\mathrm{H}_{2}$, are present [34]. Depending on the coal type, it may have a varied composition and heating value. In this study, coal is defined as an unconventional component for the purpose of simulation and the composition of coal is shown in Table 1. The heating value and density of the coal are specified using the HCOALGEN and DCOALGEN models respectively in the Aspen Plus. RGIBBS reactor model which is based on the minimization of Gibbs free energy is used as the gasifier in the simulation. WGS reactor is based on the REquil reactor model since the reaction stoichiometry is known and the reaction reach its chemical equilibrium. For the methanol synthesis, RPlug reactor has been employed using Vanden Bussche and Froment [35] reaction kinetics with adjusted parameters [18]. RPlug assumes that perfect mixing happens in the radial direction and that no mixing happens in the axial direction. The key specifications used in the Aspen Plus simulations are shown in Table 2. Finally, the proposed designs are compared in terms of energy consumption, methanol production, carbon emissions, and economic feasibility.

Table 1. Composition of coal used in the study.

\begin{tabular}{cccccc}
\hline \multicolumn{2}{c}{ Proximate Analysis } & \multicolumn{2}{c}{ Ultimate Analysis } & \multicolumn{2}{c}{ Sulfur Content } \\
\hline Element & Value & Element & Value & Element & Value \\
\hline Moisture & 9.53 & Ash & 9.66 & Pyritic & 100 \\
Fixed Carbon & 50.91 & Carbon & 74.45 & Sulfate & 0 \\
Volatile matter & 39.45 & Hydrogen & 4.95 & Organic & 0 \\
Ash & 9.64 & Nitrogen & 1.58 & & \\
& & Chlorine & 0.065 & & \\
& & Sulfur & 2.44 & & \\
& & Oxygen & 6.84 & & \\
\hline
\end{tabular}

Table 2. Key specifications used in the simulation.

\begin{tabular}{ccc}
\hline Equipment & Description & Aspen Model \\
\hline Coal flowrate & $\begin{array}{c}\text { Coal }=34.95 \mathrm{~kg} / \mathrm{s} \\
(65 \% \text { coal, } 35 \% \text { water })\end{array}$ & - \\
\hline Gasifier & $\begin{array}{c}\text { Temperature }=1300{ }^{\circ} \mathrm{C} \\
\text { Pressure }=50 \text { bar } \\
\text { Carbon conversion }=99 \%\end{array}$ & RYield, RGibbs \\
\hline Water gas shift & $\begin{array}{c}\text { Reactor configuration }=2 \text { stage } \\
\text { Overall CO conversion }=99.5 \%\end{array}$ & REquil \\
\hline Methanol reactor & $\begin{array}{r}\text { Temperature }=210{ }^{\circ} \mathrm{C} \\
\text { Pressure }=76 \text { bar } \\
\text { Cu-based catalyst } \\
\text { Catalyst density }=1725 \mathrm{~kg} / \mathrm{m}^{3} \\
\text { Bed voidage }=0.4\end{array}$ & RPlug \\
\hline Methanol distillation & $\begin{array}{c}\text { Product purity } \geq 99 \mathrm{~mol} \% \\
\text { Reflux ratio }=1.5\end{array}$ & Radfrac \\
\hline
\end{tabular}




\section{Process Description}

\subsection{Base Case Design}

The CTM base case design consists of four steps as shown in Figure 2. The first section in the process is coal preparation and gasification where the coal is grinded to prepare a coal slurry with 35 wt.\% water. A calculator block is installed using a Fortran statement to calculate the required water flowrate for the desired coal slurry composition. The coal slurry is pumped to an elevated pressure of 50 bar before feeding it to the gasifier. The high temperature entrained-flow gasifier is fed with a controlled amount of 95 mol.\% pure oxygen. The coal is gasified at $1300{ }^{\circ} \mathrm{C}$ and 50 bar with $99 \%$ carbon conversion forming ash, slag and raw syngas. Most of the slag leaves at the bottom of the gasifier, while the ash and other particulates are removed in a cyclone separator. The high temperature and high pressure raw syngas is cooled by exchanging heat to produce steam which is used to generate power through a steam cycle. Steam generated from the gasifier is also used in the WGS which is located downstream of the syngas cleaning unit. The raw syngas contains varying concentrations of $\mathrm{H}_{2} \mathrm{~S}, \mathrm{COS}$ and SOx depending on the coal type used. These sulfur based compounds must be removed from the syngas as they can poison the catalyst employed in the WGS reactor and methanol synthesis reactor. The maximum $\mathrm{H}_{2} \mathrm{~S}$ quantity allowed in the methanol synthesis reactor should be no more than 100 ppbv. For this purpose, the raw syngas is routed to the gas cleaning unit, where a physical solvent is employed to remove the unwanted sulfur components. The gas cleaning unit is a conventional absorber-regenerator system where low temperature methanol at $-34{ }^{\circ} \mathrm{C}$ is used as a solvent to absorb the sulfur components along with some $\mathrm{CO}_{2}$ in the absorber. The syngas free of $\mathrm{H}_{2} \mathrm{~S}$ is then routed to $\mathrm{CO}_{2}$ capture unit where chilled methanol is employed the remove $95 \%$ of the $\mathrm{CO}_{2}$. Design Spec function in Aspen Plus has been used to adjust the lean solvent flowrate for the desired level of acid gases removal from the syngas. The syngas produced from the coal gasification usually have a low stoichiometric number (SN) which is defined in Equation (2).

$$
\mathrm{SN}=\frac{\mathrm{H}_{2}-\mathrm{CO}_{2}}{\mathrm{CO}+\mathrm{CO}_{2}}
$$

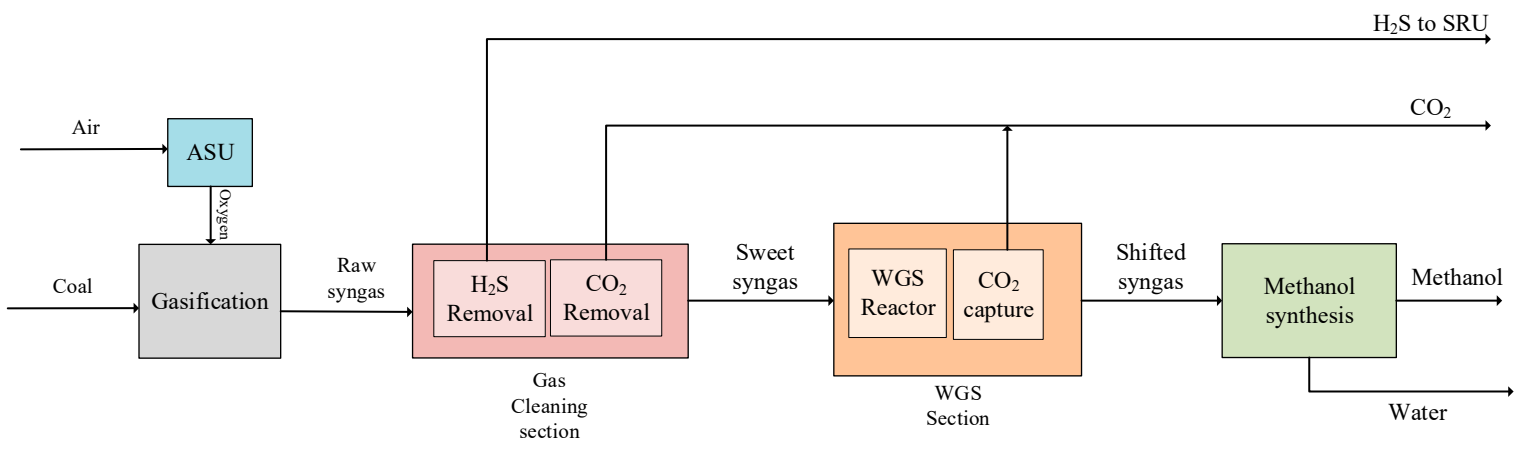

Figure 2. Block flow diagram for the base case CTM process.

It has been widely reported in the literature that a methanol reactor should be operated with a stoichiometric number of 2 for maximum efficiency $[8,36,37]$. Therefore, in order to increase the $\mathrm{H}_{2}$ content, the cleaned syngas is passed through a two-stage WGS unit where the CO reacts with steam to form $\mathrm{CO}_{2}$ and $\mathrm{H}_{2}$ as shown in Equation (3).

$$
\mathrm{CO}+\mathrm{H}_{2} \mathrm{O} \leftrightarrow \mathrm{CO}_{2}+\mathrm{H}_{2} \quad \Delta \mathrm{H}=-41 \mathrm{~kJ} / \mathrm{mol}
$$

The steam supplied to the WGS reactor comes from the gasification section. The WGS reaction is an exothermic reaction increasing the temperature of the first stage effluent to around $395^{\circ} \mathrm{C}$ which 
is cooled before feeding it to the second reactor. The steam flowrate required in the WGS reactor is manipulated using Design Spec function to achieve 99.5\% conversion of CO. Additional $\mathrm{CO}_{2}$ capture unit is installed in the WGS section to remove the excess $\mathrm{CO}_{2}$ in order to maintain the SN of 2. The SN is maintained by adjusting the $\mathrm{CO}_{2}$ removal rate in the WGS section using the Design Spec function. The clean and shifted syngas is then fed to the catalytic packed bed methanol reactor at $210{ }^{\circ} \mathrm{C}$ and 76 bar where the crude methanol is produced by the reaction shown in Equation (4).

$$
\mathrm{CO}_{2}+3 \mathrm{H}_{2} \leftrightarrow \mathrm{CH}_{3} \mathrm{OH}+\mathrm{H}_{2} \mathrm{O} \quad \Delta \mathrm{H}=-49.47 \mathrm{~kJ} / \mathrm{mol}
$$

The crude methanol is separated from the unreacted gas stream by reducing the reactor effluent temperature and pressure. The unreacted syngas is recycled back to the reactor with small amount being purged to limit the inert gas accumulation, while the $99.4 \mathrm{~mol} \%$ pure methanol is produced by distillation.

\subsection{Modified Design 1 (MD1)}

The modified design 1 proposed in this study contains the gasification, $\mathrm{H}_{2} \mathrm{~S}$ gas cleaning, WGS, and methanol synthesis sections similar to the base case design as shown in Figure 3. However, the main difference is the absence of $\mathrm{CO}_{2}$ removal unit in the gas cleaning section compared to the base case design. In MD1, all the $\mathrm{CO}_{2}$ is captured after the WGS reactor in contrast to the base case design where most of the $\mathrm{CO}_{2}$ produced in the gasifier is removed prior to the WGS reactor and $\mathrm{CO}_{2}$ produced from the shift reaction is captured in a separate unit. This design alternative offers energy and cost savings due to the removal of $\mathrm{CO}_{2}$ capture unit in the gas cleaning section. On the other hand, the WGS reactor size and utilities consumption are increased because of the larger syngas flowrate. All the design variables are kept same as that of the base case design.

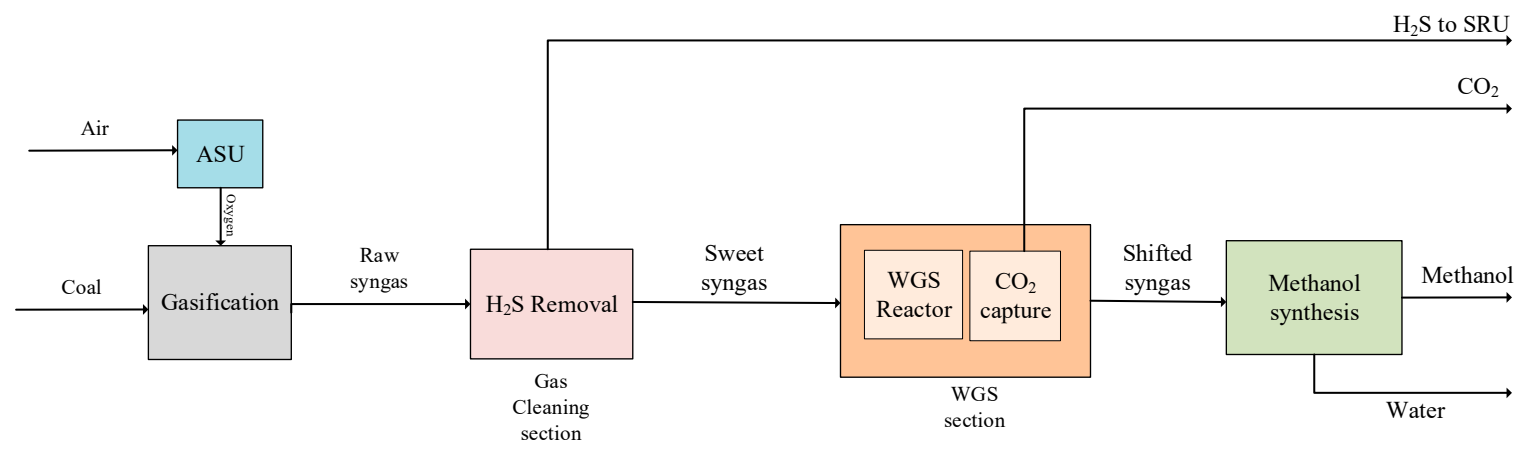

Figure 3. Block flow diagram for the modified design-1 (MD1-CTM) process.

\subsection{Modified Design $2(M D 2)$}

The modified design 2 contains the gasification, $\mathrm{H}_{2} \mathrm{~S}$ gas cleaning, WGS and methanol synthesis sections, however, no $\mathrm{CO}_{2}$ is captured and removed from the process. Figure 4 shows the simplified block flow diagram for the MD2. The $\mathrm{CO}_{2}$ produced from the gasification unit and WGS reaction is directed to the methanol synthesis. However, in order to maintain the SN at the inlet of the methanol reactor, an additional quantity of external $\mathrm{H}_{2}$ is added to the process. In this study, the external $\mathrm{H}_{2}$ is assumed to be available from the alkaline water electrolysis plant costing an energy consumption of $4.5 \mathrm{kWh} / \mathrm{m}^{3}$ of $\mathrm{H}_{2}$ [38]. The energy consumption, and consequently the production cost of $\mathrm{H}_{2}$ from the electrolysis, is on the high side compared to the conventional process mainly because of the expensive electrodes employed in the process. This design alternative offers significant energy savings in gas cleaning and WGS sections together with higher methanol production and low carbon emissions. However, all of these benefits are negated by the high cost of external $\mathrm{H}_{2}$ supply to maintain the $\mathrm{SN}$ in the methanol synthesis section. 


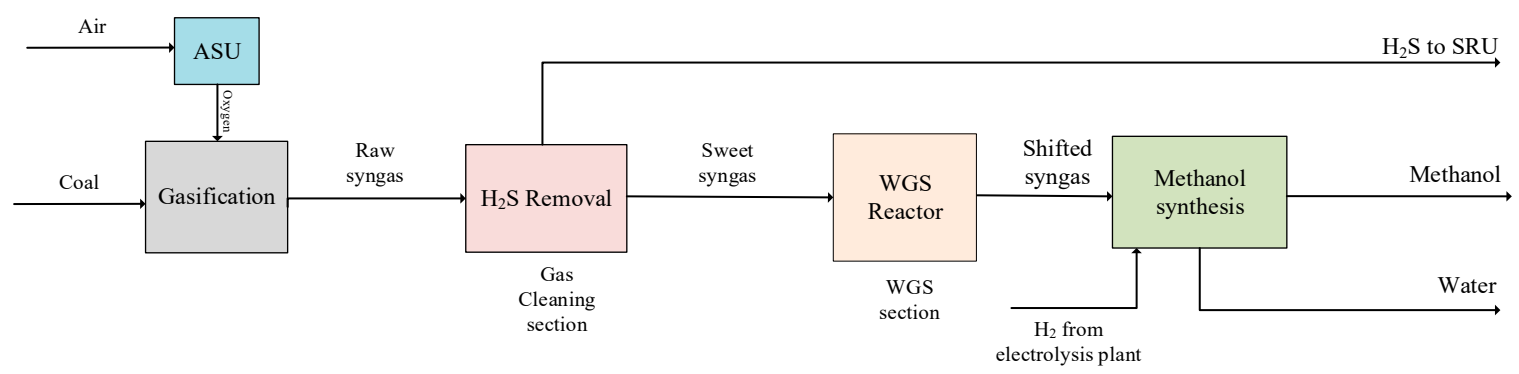

Figure 4. Block flow diagram for the modified design-2 (MD2-CTM) process.

\subsection{Modified Design 3 (MD3)}

In modified design 3 , both the $\mathrm{CO}_{2}$ cleaning and WGS units have been removed from the flowsheet as shown in Figure 5. The syngas from the gasification unit is sent to the $\mathrm{H}_{2} \mathrm{~S}$ cleaning unit for the removal of sulfur compounds. The cleaned syngas mainly containing $\mathrm{CO}, \mathrm{CO}_{2}$ and $\mathrm{H}_{2}$ is then routed to the methanol synthesis block. Similar to MD2, additional $\mathrm{H}_{2}$ is added from the electrolyser in order to maintain the SN at the inlet of the methanol reactor. This design offers better process performance in terms of lower carbon emissions, higher methanol production and lower capital cost compared to the MD2-CTM. However, similar to the MD2-CTM case, an expensive external $\mathrm{H}_{2}$ supply from the electrolyser makes the overall process infeasible. The quantitative analysis in terms of design performance indicators is discussed in the following sections. The stream information for all the four cases is shown in Table 3.

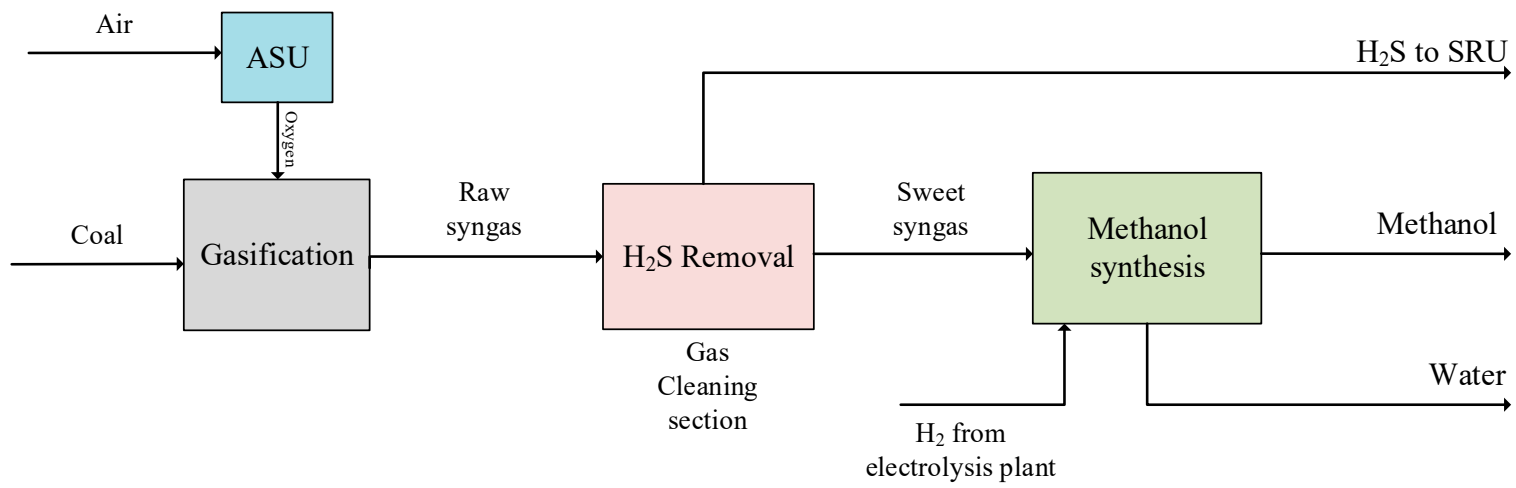

Figure 5. Block flow diagram for the modified design-3 (MD3-CTM) process. 
Table 3. Main stream information for the four cases.

\begin{tabular}{|c|c|c|c|c|c|c|c|c|c|c|c|c|c|c|c|c|}
\hline & & \multirow{2}{*}{$\begin{array}{c}\text { Coal Feed } \\
\text { BC/MD1/ } \\
\text { MD2/MD3 }\end{array}$} & \multirow{2}{*}{$\begin{array}{c}\text { Raw Syngas } \\
\text { BC/MD1/ } \\
\text { MD2/MD3 }\end{array}$} & \multirow{2}{*}{$\begin{array}{c}\mathrm{H}_{2} \mathrm{~S} \text { to SRU } \\
\text { BC/MD1/ } \\
\text { MD2/MD3 }\end{array}$} & \multicolumn{2}{|c|}{$\mathrm{CO}_{2}$} & \multicolumn{2}{|c|}{ Sweet Syngas } & \multicolumn{3}{|c|}{ Shifted Syngas } & \multirow{2}{*}{$\begin{array}{c}\text { Ext. } \mathrm{H}_{2} \\
\text { MD2/ } \\
\text { MD3 }\end{array}$} & \multicolumn{4}{|c|}{ Methanol } \\
\hline & & & & & BC & MD1 & BC & $\begin{array}{l}\text { MD1/ } \\
\text { MD2/ } \\
\text { MD3 }\end{array}$ & BC & MD1 & MD2 & & BC & MD1 & MD2 & MD3 \\
\hline Temp. & ${ }^{\circ} \mathrm{C}$ & 55 & 152.5 & -9.5 & -31.6 & -27.6 & 93.3 & 93.3 & -1.2 & -2.4 & 0.0 & 25.0 & 52.5 & 52.3 & 52.5 & 33.1 \\
\hline Pressure & bar & 50 & 27.6 & 1.1 & 1.0 & 1.0 & 27.6 & 27.6 & 24.1 & 24.1 & 24.1 & 30.0 & 1.0 & 1.0 & 1.0 & 1.0 \\
\hline Mass flowrate & $\mathrm{t} / \mathrm{h}$ & 193.6 & 284.7 & 13.0 & 148.1 & 157.3 & 169.5 & 224.3 & 165.2 & 165.7 & 322.4 & 21.5 & 81.6 & 86.0 & 174.6 & 197.6 \\
\hline Mole flowrate & $\mathrm{kmol} / \mathrm{h}$ & & 13,924 & 314 & 3387 & 3588 & 9714 & 10,970 & 12,815 & 12,850 & 16,420 & 10,660 & 2552 & 2693 & 5463 & 6168 \\
\hline Comp. & mole.fr & & & & & & & & & & & & & & & \\
\hline $\mathrm{N}_{2}$ & & - & 0.009 & 0.002 & 0.001 & 0.000 & 0.012 & 0.011 & 0.009 & 0.009 & 0.007 & 0.000 & 0.000 & 0.000 & 0.000 & 0.000 \\
\hline $\mathrm{Ar}$ & & - & 0.009 & 0.002 & 0.001 & 0.001 & 0.012 & 0.011 & 0.009 & 0.009 & 0.007 & 0.000 & 0.000 & 0.000 & 0.000 & 0.000 \\
\hline $\mathrm{H}_{2} \mathrm{O}$ & & - & 0.190 & 0.000 & 0.000 & 0.000 & 0.000 & 0.000 & 0.000 & 0.000 & 0.000 & 0.000 & 0.008 & 0.008 & 0.008 & 0.005 \\
\hline $\mathrm{CO}$ & & - & 0.394 & 0.025 & 0.006 & 0.000 & 0.561 & 0.499 & 0.002 & 0.002 & 0.002 & 0.000 & 0.000 & 0.000 & 0.000 & 0.000 \\
\hline $\mathrm{CO}_{2}$ & & - & 0.107 & 0.783 & 0.985 & 0.992 & 0.002 & 0.113 & 0.244 & 0.244 & 0.407 & 0.000 & 0.002 & 0.002 & 0.002 & 0.005 \\
\hline $\mathrm{H}_{2} \mathrm{~S}$ & & - & 0.004 & 0.162 & 0.000 & 0.000 & 0.000 & 0.000 & 0.000 & 0.000 & 0.000 & 0.000 & 0.000 & 0.000 & 0.000 & 0.000 \\
\hline $\mathrm{H}_{2}$ & & - & 0.288 & 0.005 & 0.003 & 0.003 & 0.413 & 0.366 & 0.736 & 0.736 & 0.576 & 1.000 & 0.000 & 0.000 & 0.000 & 0.000 \\
\hline $\mathrm{CH}_{3} \mathrm{OH}$ & & - & 0.000 & 0.016 & 0.003 & 0.004 & 0.000 & 0.000 & 0.000 & 0.000 & 0.000 & 0.000 & 0.990 & 0.989 & 0.990 & 0.990 \\
\hline
\end{tabular}




\section{Results and Discussions}

\subsection{Energy Analysis}

Energy efficiency is calculated for the developed designs based on the first law of thermodynamics as shown in Equation (5).

$$
\text { Energy Efficiency }=\frac{\text { Energy content in } \mathrm{MeOH}+\text { Heat \& Power }}{\text { Feed heating value }+ \text { Energy Consumed }} \times 100[\%]
$$

The calculated energy efficiencies for the four configurations are shown in Figure 6. The results show that base case design has the lowest efficiency among all the designs while MD3 has the highest efficiency. Feedstock heating value is same for all the cases, however, amount of methanol produced and energy requirement for each design is different. A detailed energy analysis has been performed in order to identify and improve the most energy consuming sections. Figure 7 shows the breakdown of energy requirement in terms of percent energy share for the base case and modified designs. For the base case and MD1, WGS section is the most energy consuming part of the plant contributing to $36 \%$ and $45 \%$ respectively, of the total energy requirement. The second most energy consuming section for the base case and MD1 is methanol synthesis section. Methanol synthesis is one of the energy intensive sections in the CTM process because of the severe operating conditions required in the methanol reactor. The methanol reactor operates at a high temperature and high pressure for the conversion of feed gas streams to the methanol product. In this study, the reactor effluent stream is at $270{ }^{\circ} \mathrm{C}$ and 76 bar. In order to have an efficient separation structure, the reactor effluent stream is cooled down and the pressure is reduced to near atmospheric pressure conditions. The single pass conversion of methanol reactor is low, which requires the huge recycle stream to be compressed back to the reactor pressure. Therefore, the above-mentioned reactor feed preparation and separator feed preparation steps require significant energy, with cooling being the most contributing utility in the methanol synthesis section. The energy requirement in the gas cleaning section for MD1 is almost reduced to half compared to the base case because of no $\mathrm{CO}_{2}$ capture unit. However, the consequence of this change is visible in the WGS section of MD1, where the energy requirement increased significantly, since $\mathrm{CO}_{2}$ removal unit is installed downstream of WGS reactor. Since, the coal feed rate and gasification process is same for all the cases, the energy requirement for (ASU + Gasification) for all the designs is $42.47 \mathrm{MW}$. In the case of MD2 and MD3, the energy requirement share in the cleaning section reduces significantly, since only $\mathrm{H}_{2} \mathrm{~S}$ is removed from the syngas and no $\mathrm{CO}_{2}$ capture unit is installed. However, in order to maintain the stoichiometric ratio of 2 at the inlet of methanol synthesis reactor, external $\mathrm{H}_{2}$ is supplied for MD2 and MD3, which is assumed to be supplied by the electrolysis plant. The results show that, electrolyser plant contributes more than 58\% and 69\% of the energy requirement in the case of MD2 and MD3 respectively. An insight into the methanol synthesis section reveals that around $70 \%$ of the energy requirement is from the cooling utilities, while the heating utilities and electricity to operate compressors contribute around $20 \%$ and $10 \%$, respectively. 


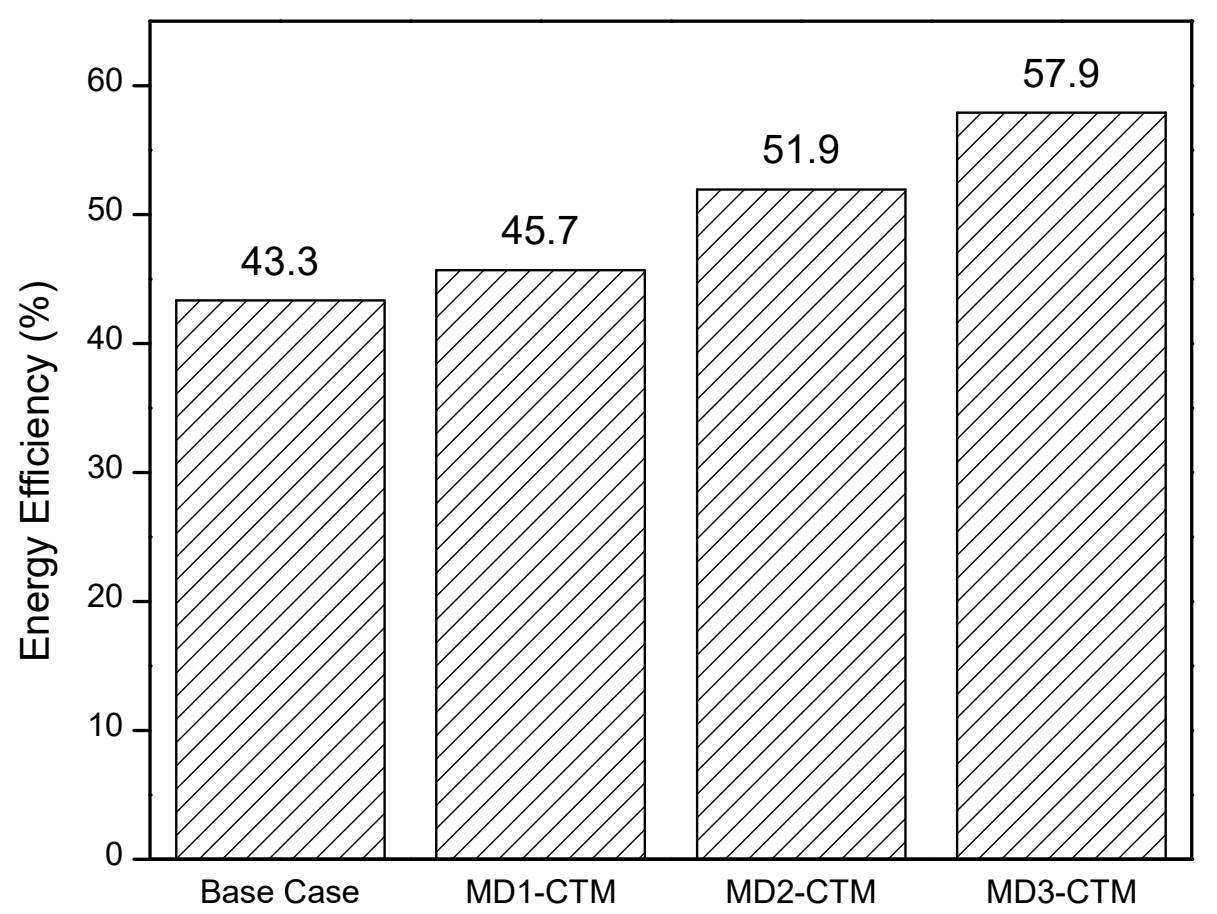

Figure 6. Energy efficiencies based on the first law of thermodynamics.

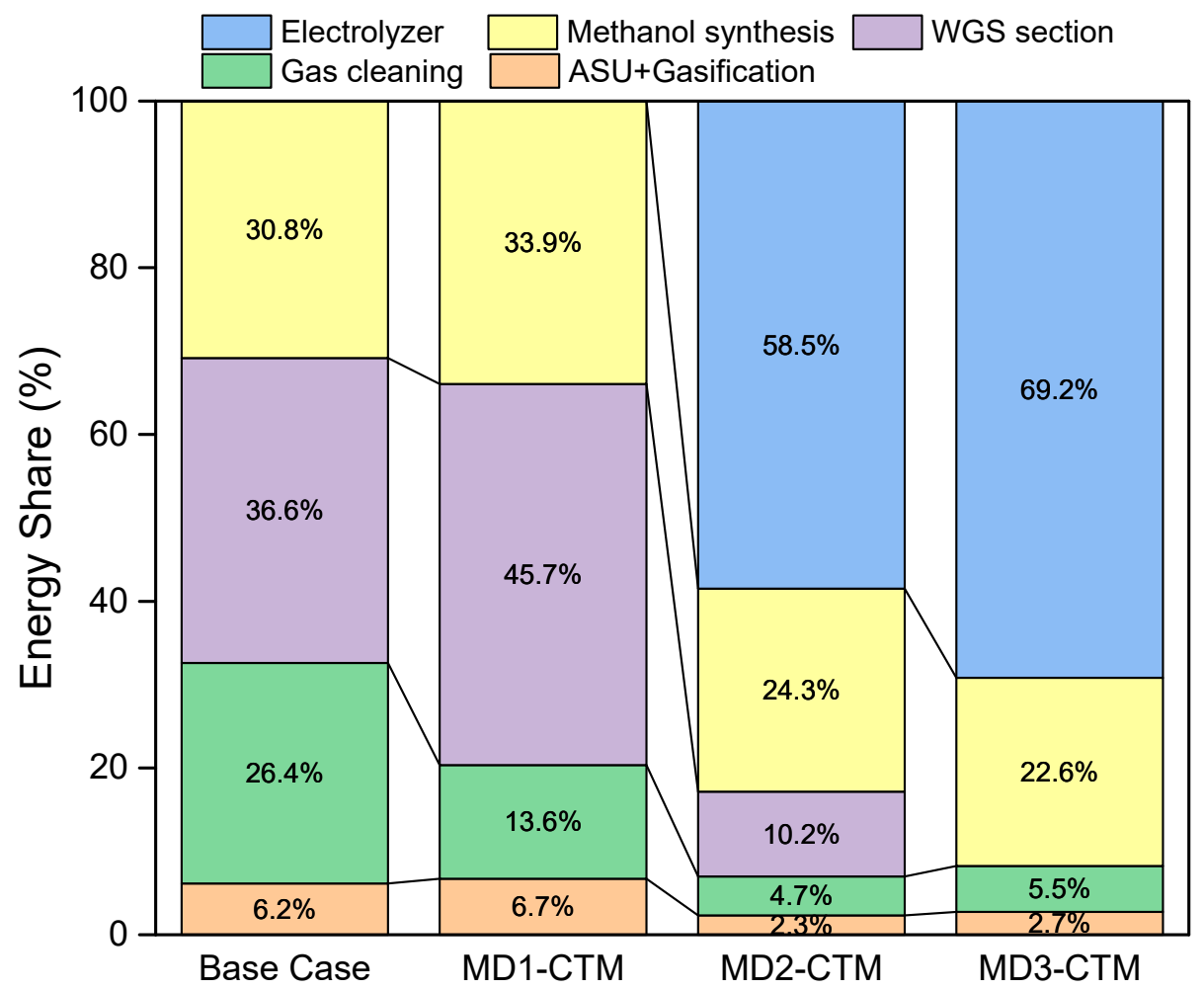

Figure 7. Breakdown of percent energy requirement for the four CTM processes.

Figure 8 shows the total energy requirement and energy requirement per ton of methanol produced. The results show that MD1 requires the least amount of energy per unit production of methanol, while the MD2 consumes the most energy per unit of methanol product. In the case of MD1 where $\mathrm{CO}_{2}$ capture unit is only located in the WGS section, around $9 \%$ energy savings are achieved compared 
to the base case design. This improvement is mainly attributed to the better resource utilization and optimizing the $\mathrm{CO}_{2}$ capture rate. The energy requirement per unit ton of methanol production reported in the literature based on the various reforming technologies range between 33.4-37.2 GJ [39]. As evident from the results, energy consumption per unit ton of methanol production for all the designs is competitive compared to the reforming technologies.

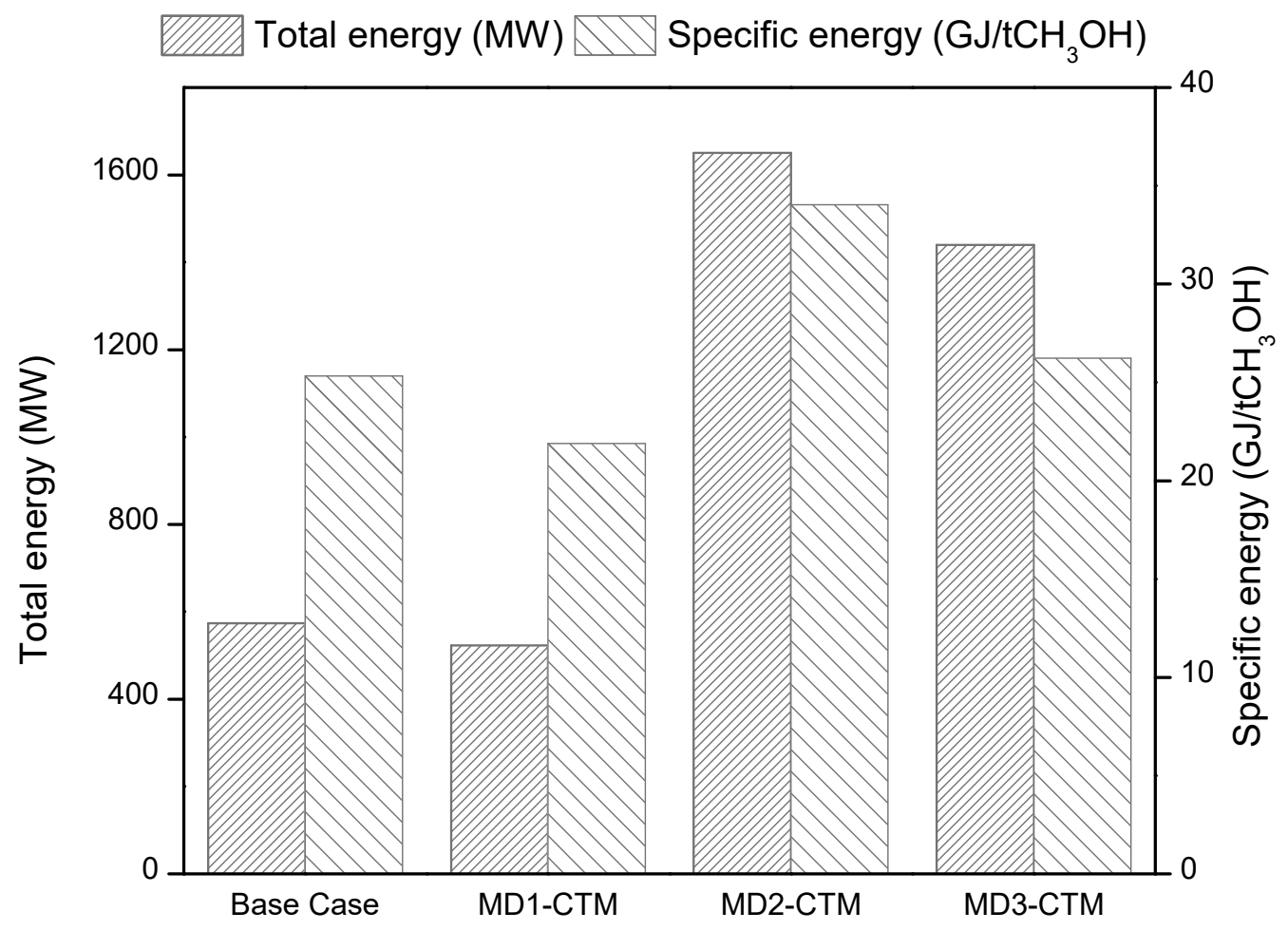

Figure 8. Total and specific energy requirement for the four CTM processes.

\subsection{Methanol Production Rate}

All the designs for the methanol production developed in this study assume an identical coal feed rate of 125.8 ton/h. Hence, the composition of raw syngas produced at the outlet of the gasifier is same for all the designs. However, due to different design configurations based on the availability and location of $\mathrm{CO}_{2}$ removal unit, WGS unit and external $\mathrm{H}_{2}$ supply, the amount of methanol production varies for all the designs. Figure 9 shows the methanol production rates for the base case, MD1, MD2 and MD3. Methanol production increases around 5\% for the MD1 compared to the base case because of an optimized $\mathrm{CO}_{2}$ removal rate. On the other hand, methanol production for MD2 and MD3 increased around 2.1 and 2.4 times compared to the base case design. The significant increase in the methanol production is due to the presence of an extra amount of carbon in the methanol reactor which has not been removed in the $\mathrm{CO}_{2}$ capture unit. The results show that the single pass conversion for the base case, MD1, and MD2 is $19.6 \%, 22.5 \%$, and $20.2 \%$ respectively. On the other hand, in the case of MD3 where the feed at the inlet of methanol synthesis reactor contains $\mathrm{CO}$ in addition to $\mathrm{H}_{2}$ and $\mathrm{CO}_{2}$, the production of methanol is positively impacted by the $\mathrm{CO}$ presence. Single pass conversion is calculated to be $13.5 \%$ and $57.8 \%$ for the $\mathrm{CO}_{2}$ and $\mathrm{CO}$, respectively. 


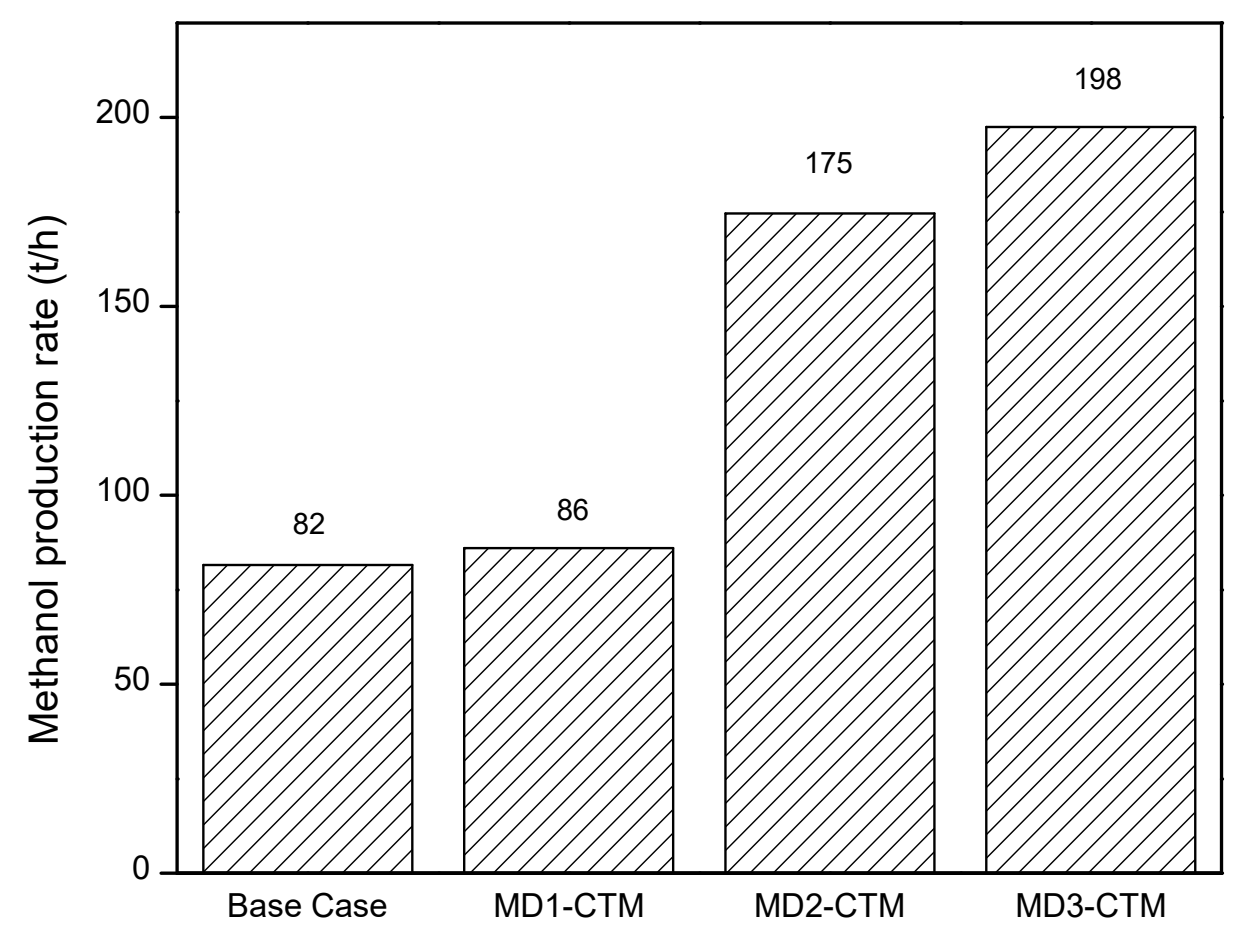

Figure 9. Methanol production rates for the four CTM processes.

\subsection{Carbon Emissions}

The main aim of various designs developed in this study is to utilize the $\mathrm{CO}_{2}$ emissions produced from the CTM process. Therefore, it is pertinent to investigate the amount of $\mathrm{CO}_{2}$ emissions produced from the proposed designs. Some of the standard environmental performance indicators such as $\mathrm{CO}_{2}$ specific emissions and carbon efficiency are investigated in this section. $\mathrm{CO}_{2}$ specific emission is the defined as the amount of emitted $\mathrm{CO}_{2}$ from the process per unit of the methanol production as shown in Equation (6).

$$
\mathrm{CO}_{2} \text { specific emissions }=\frac{\mathrm{CO}_{2} \text { emissions }\left(\frac{\mathrm{kg}}{\mathrm{h}}\right)}{\text { Methanol production }\left(\frac{\mathrm{kg}}{\mathrm{h}}\right)}
$$

Figure 10 shows the $\mathrm{CO}_{2}$ specific emissions for the four cases. The results show that base case and MD1 have almost the same $\mathrm{CO}_{2}$ specific emissions, however, the $\mathrm{CO}_{2}$ specific emissions for MD2 and MD3 are approximately 85\% and 93\% lower compared to the base case design. The significant reduction in the $\mathrm{CO}_{2}$ specific emissions is due to the higher utilization of carbon content by the addition of external $\mathrm{H}_{2}$.

Carbon efficiency is another variable which shows the amount of carbon present in the feed to the desired product. The carbon present in the coal is mainly converted to $\mathrm{CO}_{2}$ and $\mathrm{CO}$ with small quantities of $\mathrm{CH}_{4}, \mathrm{COS}$ and ash. Equation (7) shows the relation for the calculation of carbon efficiency $\left(\eta_{\mathrm{C}}\right)$, which is defined as the ratio of carbon content in the methanol to the carbon content in all the components of the feed stream.

$$
\eta_{\mathrm{C}}=\frac{\text { Carbon }_{\mathrm{MeOH}}}{\text { Carbon }_{\mathrm{feed}}}[\%]
$$

The results show that the carbon efficiency for the MD2 and MD3 is around $41 \%$ and $51 \%$ higher respectively compared to the base case design as shown in Figure 11. The higher carbon efficiency is directly related to the lower carbon specific emission and higher methanol production rate, as shown previously. 


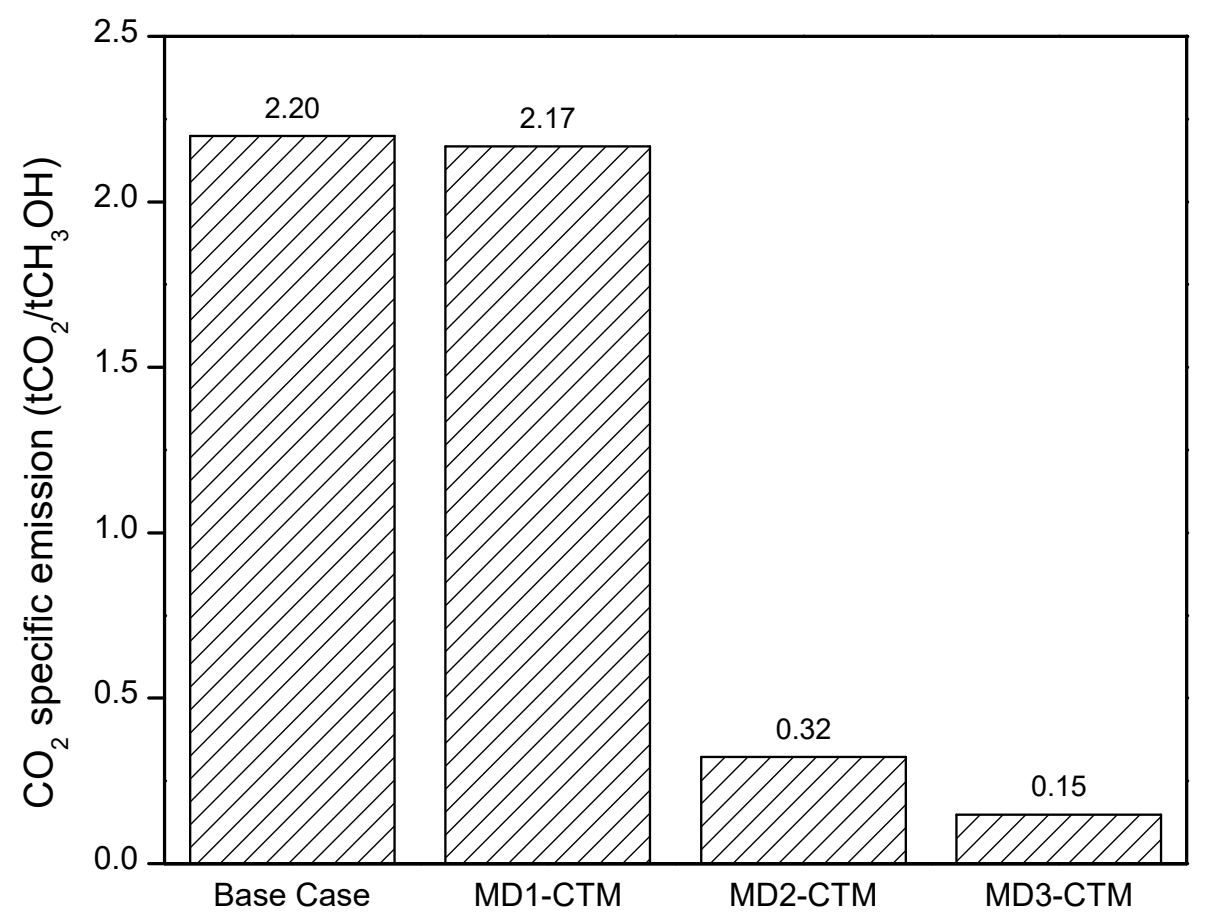

Figure 10. $\mathrm{CO}_{2}$ specific emissions for the four CTM processes.

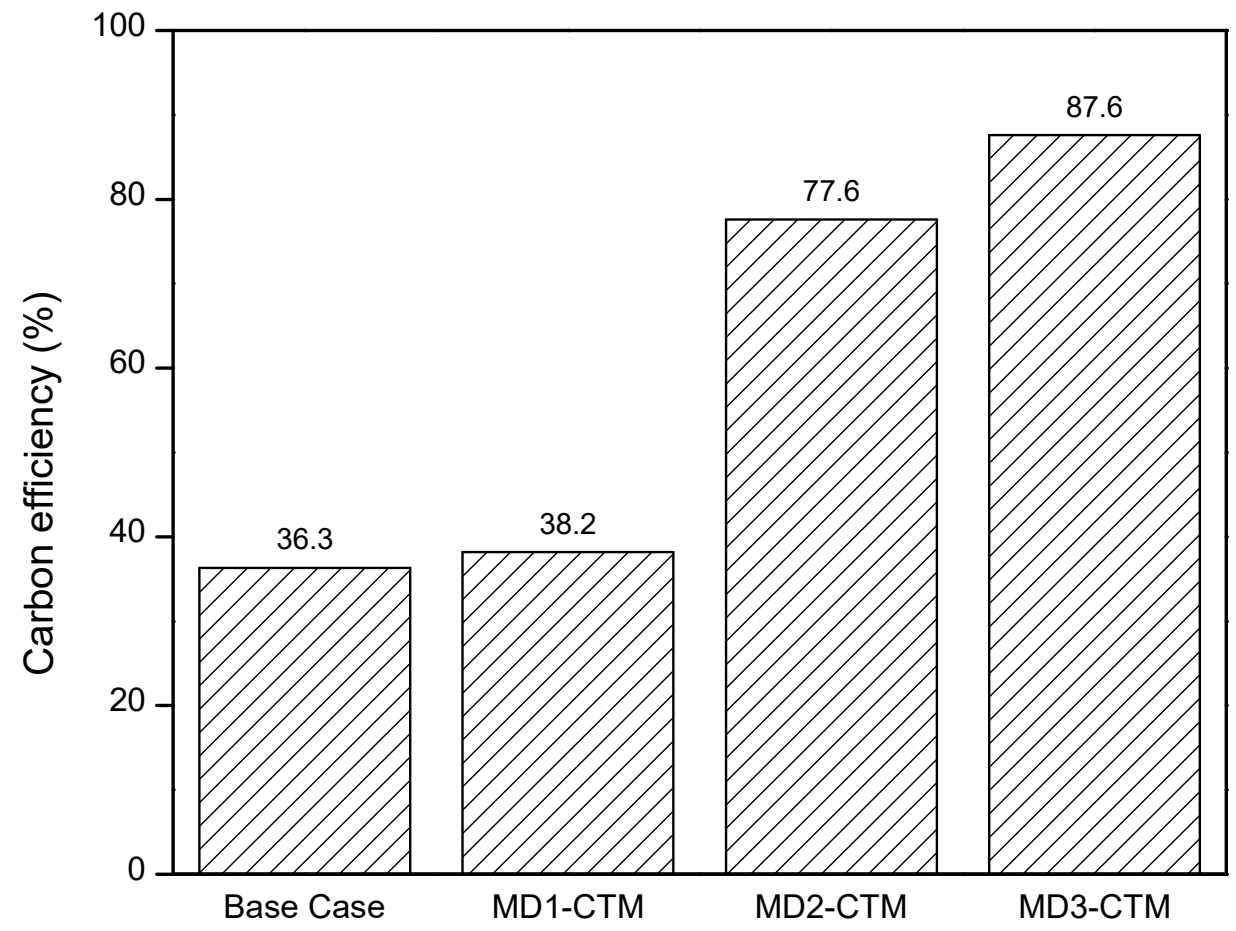

Figure 11. Carbon efficiencies for the four CTM processes.

\subsection{Economic Analysis}

The results discussed in the previous sections clearly show that the MD2 and MD3 configurations perform considerably better compared to the base case design in terms of methanol production rate and emissions. However, these improved results are achieved at the cost of additional $\mathrm{H}_{2}$ supplied from an electrolyser plant. Therefore, an economic analysis is performed to investigate the impact of different design configurations on the product cost. Aspen Economic Analyzer V10 has been used for 
the purpose of economic analysis along with other literature resources. The key economic assumptions in this study are shown in Table $4[13,40,41]$. The methodology employed for the calculation of product cost is a standard procedure described in the literature [34].

Table 4. Economic assumptions used in the analysis [13,40,41].

\begin{tabular}{cc}
\hline Parameter & Value \\
\hline Project life & 30 year \\
Tax rate & $25 \%$ \\
Interest rate & $10 \%$ \\
Stream factor & 0.95 \\
Salvage value & $10 \%$ of TCI \\
Depreciation & Straight line method \\
Coal price & $35 \$ / \mathrm{t}$ \\
External Hydrogen price & $2.3 \$ / \mathrm{kg}$ \\
Operating labor rate & $\$ 20 / \mathrm{operator} / \mathrm{h}$ \\
Electricity cost & $\$ 0.0775 / \mathrm{kWh}$ \\
LP steam cost & $\$ 14.05 / \mathrm{GJ}$ \\
MP steam cost & $\$ 14.83 / \mathrm{GJ}$ \\
HP steam cost & $\$ 17.70 / \mathrm{GJ}$ \\
Refrigeration cost & $\$ 13.11 / \mathrm{GJ}$ \\
\hline
\end{tabular}

Figure 12 shows the required capital expenditure (CAPEX) and annual operating cost (OPEX) for the developed cases. The results show that the CAPEX of MD1 is 4 M\$ less than the base case design due to the intensification of $\mathrm{CO}_{2}$ removal unit. The CAPEX required for the MD2 is the highest among all the designs because of the larger equipment size and addition of an electrolyser plant. The results also reveal that around 9.2 M\$ per year can be saved in the case of MD1 by slight modification of the base case design. Overall, MD3 has the highest CAPEX and OPEX among all the designs. Figure 13 shows the TAC breakdown in terms of annualized CAPEX and OPEX (including utilities and raw materials) for the four designs. As evident from the results, OPEX is the main cost contributor for all the cases. In the case of base case and MD1, utilities contribute to more than 50\% of the TAC. However, in the case of MD2 and MD3, around $80 \%$ and $86 \%$ of the TAC respectively is contributed because of an external $\mathrm{H}_{2}$ supply. Figure 14 shows the utilities consumption rate for the four designs. The electricity consumption for MD2 and MD3 is higher compared to base case and MD1 because of increase in compression energy required for an additional $\mathrm{H}_{2}$ compression in the methanol synthesis section. Since all the four designs have different methanol production rates, therefore, in order to have fair comparison, utilities cost per unit of methanol is calculated. The results show that utility cost per unit ton of methanol product for the base case, MD1, MD2, and MD3 configurations is $\$ 89.7, \$ 73.8$, $\$ 47.4$, and $\$ 34.9$ respectively. The results further reveal that in order for MD3 to be competitive with the MD1, the maximum price of external $\mathrm{H}_{2}$ should be $\$ 0.71$ per $\mathrm{kg}$ or below. Figure 15 shows the product cost per unit ton of methanol. MD1 offers the lowest methanol production cost. On the other hand, MD2 has the highest per unit cost. 


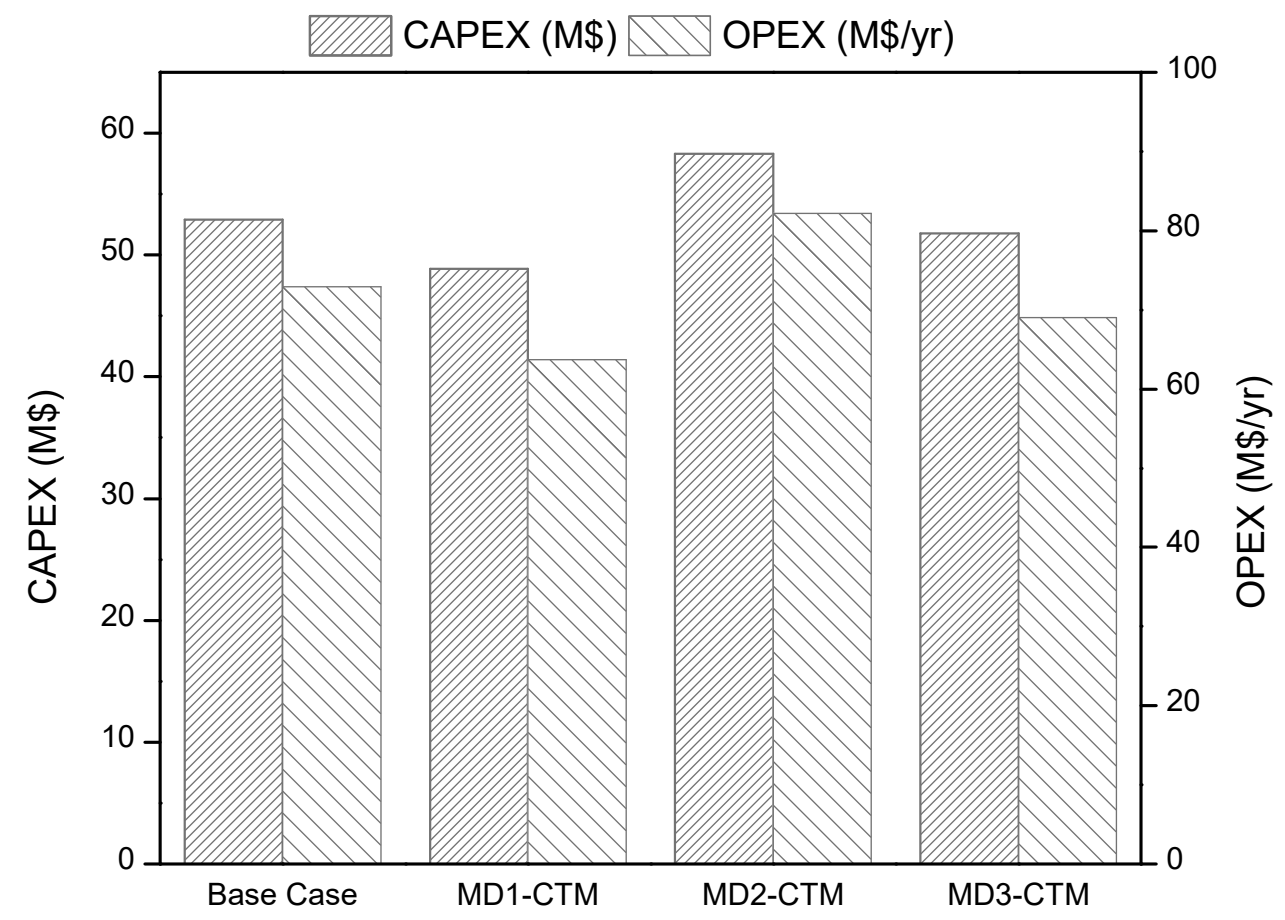

Figure 12. CAPEX and OPEX for the four CTM processes.

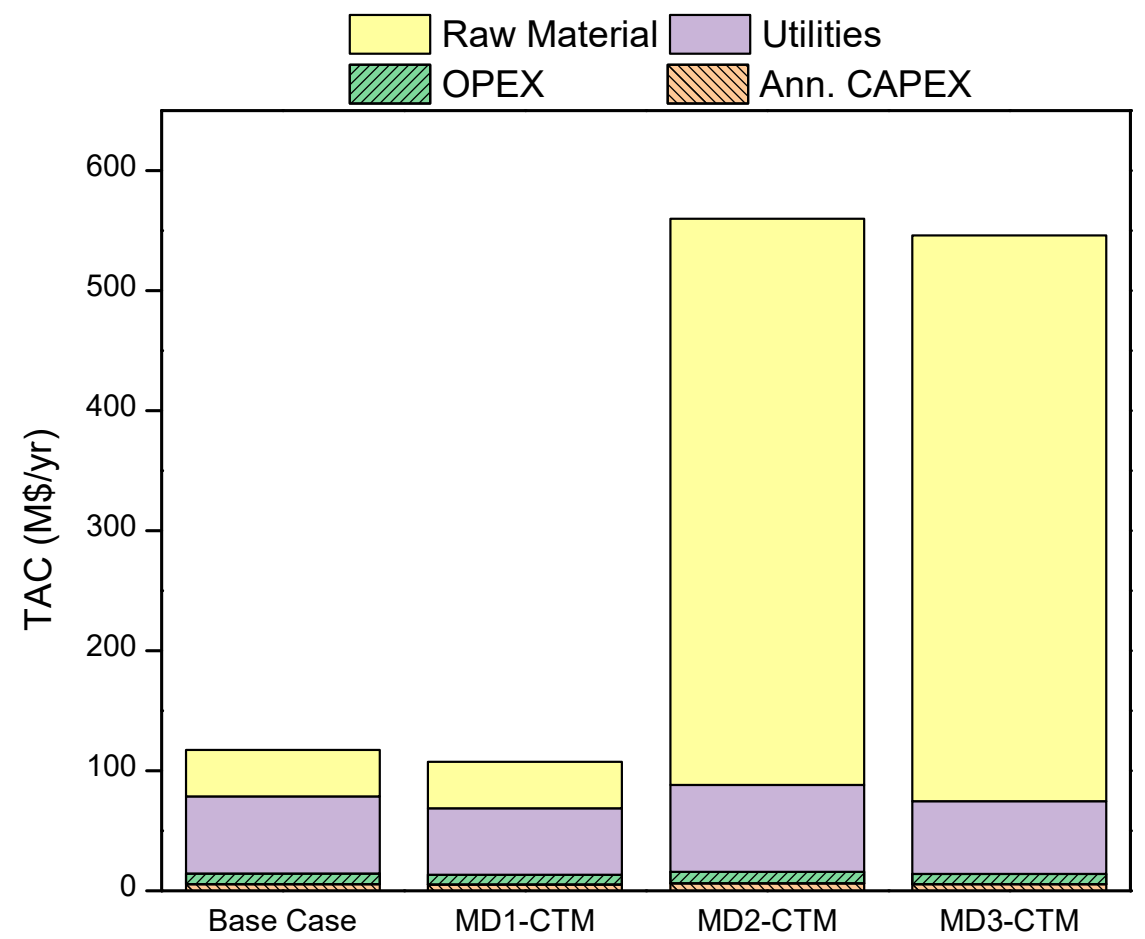

Figure 13. Total annual cost (TAC) for the four CTM processes. 


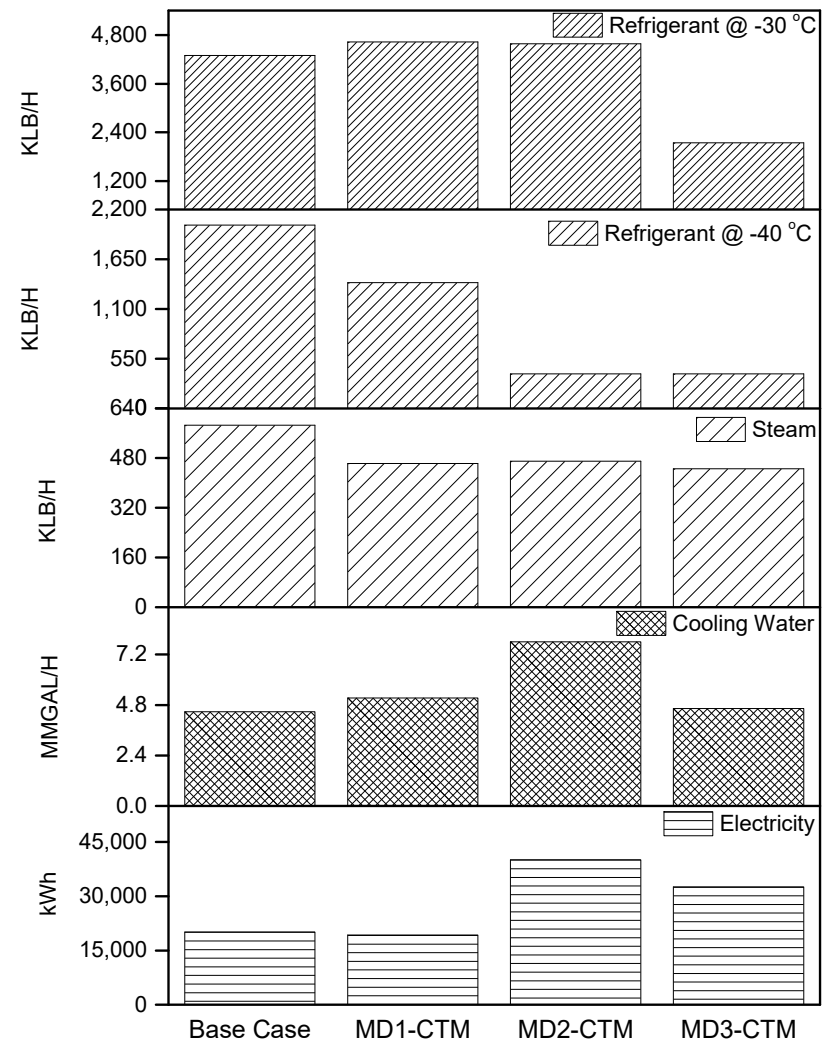

Figure 14. Utilities consumption rates for the four CTM processes.

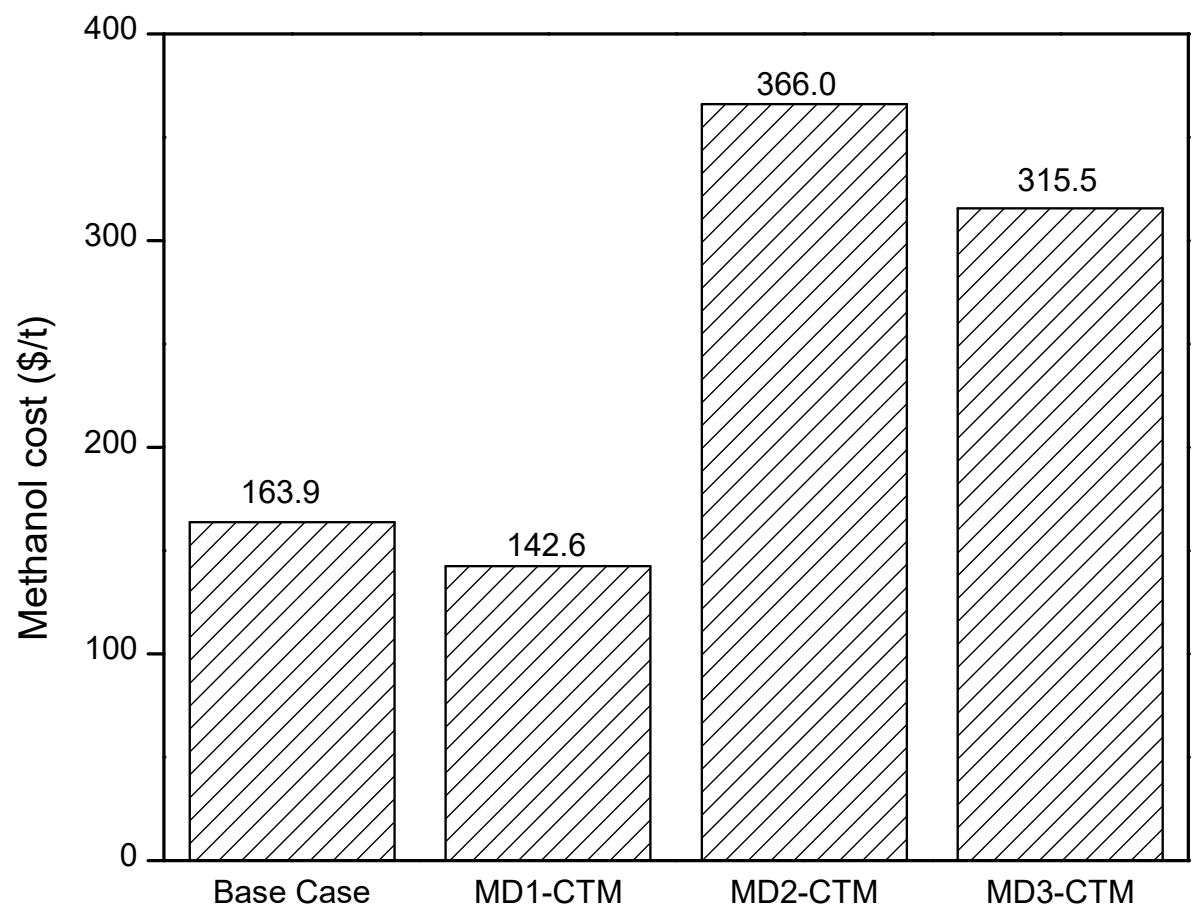

Figure 15. Methanol production cost for the four CTM processes.

\subsection{Comparative Analysis with the Literature}

In order to ascertain the performance of simulation models developed in this study, a qualitative comparison has been made to the other recent studies. Table 5 shows the comparative results in 
terms of energy efficiency, carbon efficiency, $\mathrm{CO}_{2}$ emissions, and methanol product price. The energy efficiencies of the models in this study range between $43.3 \%$ and $57.9 \%$. Depending on the feedstock, the practical efficiencies range between $40 \%$ and 55\% for the CTM process, while in the case of natural gas feed, the energy efficiency is 50-65\% [42]. The results show that the energy efficiencies of the proposed CTM processes agree with the practical efficiencies. Carbon efficiency reported in the recent studies is 37-38\% [43-45], which indicates a good match with the results of base case and MD-1 design. Moreover, MD-2 and MD-3 alternative designs have shown that the carbon efficiency can be increased to $77.6 \%$ and $87.6 \%$ respectively by utilizing more $\mathrm{CO}_{2}$ for the methanol production. As stated earlier that the goal of this study is to propose a CTM design with minimal $\mathrm{CO}_{2}$ emissions. Literature has widely reported $\mathrm{CO}_{2}$ emissions of about $2.6 \mathrm{t} / \mathrm{t}-\mathrm{CH}_{3} \mathrm{OH}$ for the $\mathrm{CTM}$ process [46]. The results show that the calculated $\mathrm{CO}_{2}$ emissions for the base case and MD-1 are relatively lower compared to the recent works. In addition, the MD-2 and MD-3 designs have the potential to significantly reduce the $\mathrm{CO}_{2}$ emissions to $0.32 \mathrm{t}$ and $0.15 \mathrm{t}$ respectively per ton of methanol production. The comparison of methanol cost with the recent works show that the per unit ton product cost for the base case and MD-1 design is lower, leading to the higher profit margins.

Table 5. Comparison of key results with the literature findings.

\begin{tabular}{|c|c|c|c|c|c|}
\hline & Base Case & MD-1 & MD-2 & MD-3 & Literature \\
\hline Energy efficiency (\%) & 43.3 & 45.7 & 51.9 & 45.7 & $\begin{array}{c}41-55[42] \\
51.0[43] \\
45.5[45]\end{array}$ \\
\hline Carbon efficiency (\%) & 36.3 & 38.2 & 77.6 & 87.6 & $\begin{array}{l}37.3[43] \\
38.4[44] \\
37.0[45]\end{array}$ \\
\hline $\mathrm{CO}_{2}$ emissions $\left(\mathrm{t} / \mathrm{t} \mathrm{CH}_{3} \mathrm{OH}\right)$ & 2.20 & 2.17 & 0.32 & 0.15 & $\begin{array}{c}2.6[43,46] \\
2.3[44] \\
5.31[45] \\
2.97[47]\end{array}$ \\
\hline Methanol cost (US $\$ / t)$ & 163.9 & 142.6 & 366.0 & 315.5 & $\begin{array}{l}267.0[43] \\
290.0[44] \\
272.6[45]\end{array}$ \\
\hline
\end{tabular}

\section{Conclusions and Recommendations}

CTM is a commercial process emitting large amount of emissions. The goal is to reduce the carbon emissions while utilizing the existing fossil fuels without adding significant process complexities. In this study, three CTM process designs are proposed and compared with the base case design employing process intensification techniques while utilizing the $\mathrm{CO}_{2}$ emissions produced from the coal gasification process. The major findings are summarized here:

1. CTM production with CCUS is technically and economically feasible process. The MD1-CTM offers the best results with an energy requirement of $21.9 \mathrm{GJ} / \mathrm{tCH}_{3} \mathrm{OH}$ and a product cost of $142.5 \$ / \mathrm{tCH}_{3} \mathrm{OH}$.

2. CTM process is complex process with many energy intensive equipment including gasification section, gas cleaning section, WGS section and methanol synthesis section. However, the process development based on intensification concepts can simplify the process, leading to significant CAPEX and OPEX savings.

3. $\mathrm{CO}_{2}$ emissions from the CTM process can be curtailed up to a certain limit. In order to further minimize the $\mathrm{CO}_{2}$ emissions from the process, $\mathrm{H}_{2}$ supply from an external source is required. In the case of CTM process integration with an electrolysis plant for the supply of clean $\mathrm{H}_{2}$, the overall economics are not feasible. 
4. The proposed MD2 and MD3 configurations have $8.6 \%$ and $14.6 \%$ higher process efficiency respectively compared to the base case design. However, the economics of these designs are not feasible. In particular, MD3 can become economically attractive if, (a) the carbon tax is implemented due to its low emission benefits; (b) technological advancement in the electrolysis process are made for the supply of clean and cheap $\mathrm{H}_{2}$.

Despite the advancements made in CTM plants focusing on $\mathrm{CO}_{2}$ utilization, the single pass conversion of the methanol synthesis reactor is still low, requiring efforts to develop new catalyst materials and improved reactor configurations. As shown in this study for the case of MD-2 and MD-3, design intensification is technically feasible but would require a cheap source of $\mathrm{H}_{2}$ supply for higher $\mathrm{CO}_{2}$ utilization and methanol production. Therefore, further investigation is needed to study the feasibility of design integration between the renewable $\mathrm{H}_{2}$ units and conventional methanol plants. Currently, acid gas cleaning technologies offer a wide range of options for the efficient removal of $\mathrm{H}_{2} \mathrm{~S}$ and $\mathrm{CO}_{2}$. There is a further need to assess gas cleaning options, including various physical and chemical solvents, ionic liquids, membranes, adsorption, and other methods that may perform better in the CTM processes. Economies of scale can affect the project's profitability. Therefore, additional case studies are required to explore the impact of methanol production capacities on the process economics.

Author Contributions: Conceptualization, U.Z.; Data curation, S.S.K.; Formal Analysis, S.S.K., U.Z., A.G.A.J., U.A. and F.S.A.; Funding acquisition, C.-J.L.; Investigation, S.S.K., A.G.A.J. and U.A.; Methodology, S.S.K. and U.A.; Software, S.S.K. and U.Z.; Supervision, U.Z. and C.-J.L.; Validation, S.S.K. and C.-J.L.; Visualization, A.G.A.J. and F.S.A.; Writing—original draft, S.S.K., U.Z. and C.-J.L.; Writing—review \& editing, S.S.K., U.Z., A.G.A.J., U.A., F.S.A. and C.-J.L. All authors have read and agreed to the published version of the manuscript.

Funding: This research was supported by the Chung-Ang University Research Grants in 2018.

Conflicts of Interest: The authors declare no conflict of interest.

\section{Nomenclature}

$\begin{array}{ll}\text { ASU } & \text { Air separation unit } \\ \text { CAGR } & \text { Compound annual growth rate } \\ \text { CAPEX } & \text { Capital expenditure } \\ \text { CCUS } & \text { Carbon capture, utilization and storage } \\ \text { DMR } & \text { Dry methane reforming } \\ \text { EOS } & \text { Equation of state } \\ \text { GHG } & \text { Greenhouse gas } \\ \text { IGCC } & \text { Integrated gasification combined cycle } \\ \text { IPCC } & \text { Intergovernmental panel on climate change } \\ \text { IRR } & \text { Internal rate of return } \\ \text { LNG } & \text { Liquefied natural gas } \\ \text { MD1 } & \text { Modified Design 1 } \\ \text { MD2 } & \text { Modified Design 2 } \\ \text { MD3 } & \text { Modified Design 3 } \\ \text { MOFs } & \text { Metal-organic frameworks } \\ \text { MTO } & \text { Methanol to olefins } \\ \text { NETL } & \text { National energy technology laboratory } \\ \text { OPEX } & \text { Operating expense } \\ \text { PR-BM } & \text { Peng-Robinson with Boston Mathias } \\ \text { SN } & \text { Stoichiometric number } \\ \text { SRU } & \text { Sulfur recovery unit } \\ \text { TAC } & \text { Total annual cost } \\ \text { TCI } & \text { Total capital investment } \\ \text { WGS } & \text { Water gas shift } \\ & \end{array}$




\section{References}

1. Hulme, M. Is it too late (to stop dangerous climate change)? An editorial. Wiley Interdiscip. Rev. Clim. Chang. 2020, 11, e619. [CrossRef]

2. Helgason, R.; Cook, D.; Davíðsdóttir, B. An evaluation of the cost-competitiveness of maritime fuels-A comparison of heavy fuel oil and methanol (renewable and natural gas) in Iceland. Sustain. Prod. Consum. 2020, 23, 236-248. [CrossRef]

3. Bazooyar, B.; Ghorbani, A.; Shariati, A. Combustion performance and emissions of petrodiesel and biodiesels based on various vegetable oils in a semi industrial boiler. Fuel 2011, 90, 3078-3092. [CrossRef]

4. Turaga, U. Small-scale methanol technologies offer flexibility, cost effectiveness. Gas Process. News 2017. Available online: http://www.gasprocessingnews.com/features/201510/small-scale-methanol-technologiesoffer-flexibility,-cost-effectiveness.aspx (accessed on 13 November 2020).

5. IHS Markit. Chemical World Analysis Long-Term Chemical Market Trends; IHS Markit: London, UK, 2019.

6. Unnasch, S.; Lawrence, M.; Pont, J. Kalama Manufacturing and Marine Export Facility Supplemental GHG Analysis; Life Cycle Associates Report: Washington, DC, USA, 2018.

7. Nguyen, T.B.H.; Zondervan, E. Methanol production from captured $\mathrm{CO}_{2}$ using hydrogenation and reforming technologies-environmental and economic evaluation. J. $\mathrm{CO}_{2}$ Util. 2019, 34, 1-11. [CrossRef]

8. Leonzio, G.; Zondervan, E.; Foscolo, P.U. Methanol production by $\mathrm{CO}_{2}$ hydrogenation: Analysis and simulation of reactor performance. Int. J. Hydrogen Energy 2019, 44, 7915-7933. [CrossRef]

9. Tamnitra, R.; Jitwung, R.; Puangpetch, T.; Patthaveekongka, W.; Leeheng, K. Kinetic modeling and simulation of bio-methanol process from biogas by using aspen plus. MATEC Web Conf. 2018, 192, 4-7. [CrossRef]

10. Šetinc, M.; Levec, J. On the kinetics of liquid-phase methanol synthesis over commercial Cu/ $/ \mathrm{nO} / \mathrm{Al}_{2} \mathrm{O}_{3}$ catalyst. Chem. Eng. Sci. 1999, 54, 3577-3586. [CrossRef]

11. Lee, H.W.; Kim, K.; An, J.; Na, J.; Kim, H.; Lee, H.; Lee, U. Toward the practical application of direct $\mathrm{CO}_{2}$ hydrogenation technology for methanol production. Int. J. Energy Res. 2020. [CrossRef]

12. Xiang, D.; Li, P.; Yuan, X. System optimization and performance evaluation of shale gas chemical looping reforming process for efficient and clean production of methanol and hydrogen. Energy Convers. Manag. 2020, 220, 113099. [CrossRef]

13. Kim, S.; Kim, M.; Kim, Y.T.; Kwak, G.; Kim, J. Techno-economic evaluation of the integrated polygeneration system of methanol, power and heat production from coke oven gas. Energy Convers. Manag. 2019, 182, 240-250. [CrossRef]

14. Ahmed, U. Techno-economic feasibility of methanol synthesis using dual fuel system in a parallel process design configuration with control on green house gas emissions. Int. J. Hydrogen Energy 2020, 45, 6278-6290. [CrossRef]

15. Agarwal, R.A. Methanol Hydrogenation Synthesis Using from Metal-Organic $\mathrm{CO}_{2}$ Frameworks. $\mathrm{CO}_{2} \mathrm{Sep}$. Purif. Convers. Chem. Fuels 2018, 79. [CrossRef]

16. Ting, K.W.; Toyao, T.; Siddiki, S.M.A.H.; Shimizu, K. Low-temperature hydrogenation of $\mathrm{CO}_{2}$ to methanol over heterogeneous TiO2-Supported Re catalysts. ACS Catal. 2019, 9, 3685-3693. [CrossRef]

17. Li, S.; Guo, L.; Ishihara, T. Hydrogenation of $\mathrm{CO}_{2}$ to methanol over $\mathrm{Cu} / \mathrm{AlCeO}$ catalyst. Catal. Today 2020, 339, 352-361. [CrossRef]

18. Van-Dal, É.S.; Bouallou, C. Design and simulation of a methanol production plant from $\mathrm{CO}_{2}$ hydrogenation. J. Clean. Prod. 2013, 57, 38-45. [CrossRef]

19. Asif, M.; Gao, X.; Lv, H.; Xi, X.; Dong, P. Catalytic hydrogenation of $\mathrm{CO}_{2}$ from $600 \mathrm{MW}$ supercritical coal power plant to produce methanol: A techno-economic analysis. Int. J. Hydrogen Energy 2018, 43, 2726-2741. [CrossRef]

20. Charoensuppanimit, P.; Kitsahawong, K.; Kim-Lohsoontorn, P.; Assabumrungrat, S. Incorporation of hydrogen by-product from $\mathrm{NaOCH}_{3}$ production for methanol synthesis via $\mathrm{CO}_{2}$ hydrogenation: Process analysis and economic evaluation. J. Clean. Prod. 2019, 212, 893-909. [CrossRef]

21. Kiss, A.A.; Pragt, J.J.; Vos, H.J.; Bargeman, G.; de Groot, M.T. Novel efficient process for methanol synthesis by $\mathrm{CO}_{2}$ hydrogenation. Chem. Eng. J. 2016, 284, 260-269. [CrossRef]

22. Luu, M.T.; Milani, D.; Bahadori, A.; Abbas, A. A comparative study of $\mathrm{CO}_{2}$ utilization in methanol synthesis with various syngas production technologies. J. $\mathrm{CO}_{2}$ Util. 2015, 12, 62-76. [CrossRef] 
23. Puig-Gamero, M.; Argudo-Santamaria, J.; Valverde, J.L.; Sánchez, P.; Sanchez-Silva, L. Three integrated process simulation using aspen plus ${ }^{\circledR}$ : Pine gasification, syngas cleaning and methanol synthesis. Energy Convers. Manag. 2018, 177, 416-427. [CrossRef]

24. Liu, Z. Economic analysis of methanol production from coal/biomass upgrading. Energy Sources Part B Econ. Plan. Policy 2018, 13, 66-71. [CrossRef]

25. Herdem, M.S.; Mazzeo, D.; Matera, N.; Wen, J.Z.; Nathwani, J.; Hong, Z. Simulation and modeling of a combined biomass gasification-solar photovoltaic hydrogen production system for methanol synthesis via carbon dioxide hydrogenation. Energy Convers. Manag. 2020, 219, 113045. [CrossRef]

26. Rivarolo, M.; Bellotti, D.; Magistri, L.; Massardo, A.F. Feasibility study of methanol production from different renewable sources and thermo-economic analysis. Int. J. Hydrogen Energy 2016, 41, 2105-2116. [CrossRef]

27. Wang, X.; Demirel, Y. Feasibility of Power and Methanol Production by an Entrained-Flow Coal Gasification System. Energy Fuels 2018, 32, 7595-7610. [CrossRef]

28. Ye, C.; Wang, Q.; Zheng, Y.; Li, G.; Zhang, Z.; Luo, Z. Techno-economic analysis of methanol and electricity poly-generation system based on coal partial gasification. Energy 2019, 185, 624-632. [CrossRef]

29. Kler, A.M.; Tyurina, E.A.; Mednikov, A.S. A plant for methanol and electricity production: Technical-economic analysis. Energy 2018, 165, 890-899. [CrossRef]

30. Gu, Y. Kokossis Modeling and Analysis of Coal-Based Lurgi Gasification for LNG and Methanol Coproduction Process. Processes 2019, 7, 688. [CrossRef]

31. McDonell, V. Key combustion issues associated with syngas and high-hydrogen fuels. In The Gas Turbine Handbook; Gulf Professional Publishing: Oxford, UK, 2006.

32. Mondal, P.; Dang, G.S.; Garg, M.O. Syngas production through gasification and cleanup for downstream applications-Recent developments. Fuel Process. Technol. 2011, 92, 1395-1410. [CrossRef]

33. Summers, W. Baseline Analysis of Crude Methanol Production from Coal and Natural Gas. Natl. Energy Technol. Lab. 2014. [CrossRef]

34. Aspen Technology, Inc. Aspen Physical Property System-Physical Property Methods; Aspen Technology, Inc.: Burlington, MA, USA, 2013.

35. Vanden Bussche, K.M.; Froment, G.F. A steady-state kinetic model for methanol synthesis and the water gas shift reaction on a commercial $\mathrm{Cu} / \mathrm{ZnO} / \mathrm{Al}_{2} \mathrm{O}_{3}$ catalyst. J. Catal. 1996, 161, 1-10. [CrossRef]

36. Bozzano, G.; Manenti, F. Efficient methanol synthesis: Perspectives, technologies and optimization strategies. Prog. Energy Combust. Sci. 2016, 56, 71-105. [CrossRef]

37. Samimi, F.; Rahimpour, M.R.; Shariati, A. Development of an efficient methanol production process for direct $\mathrm{CO}_{2}$ hydrogenation over a $\mathrm{Cu} / \mathrm{Zno} / \mathrm{Al}_{2} \mathrm{O}_{3}$ catalyst. Catalysts 2017, 7, 332. [CrossRef]

38. Santos, D.M.F.; Sequeira, C.A.C.; Figueiredo, J.L. Hydrogen production by alkaline water electrolysis. Quim. Nova 2013, 36, 1176-1193. [CrossRef]

39. M. Pérez-Fortes, E.T. Techno-Economic and Environmental Evaluation of $\mathrm{CO}_{2}$ Utilisation for Fuel Production. Synthesis of Methanol and Formic Acid; JRC Science Hub: ZG Petten, The Netherlands, 2016; ISBN 9789279591334.

40. Calise, F.; D'Accadia, M.D.; Santarelli, M.; Lanzini, A.; Ferrero, D. Solar Hydrogen Production: Processes, Systems and Technologies; Academic Press: Cambridge, MA, USA, 2019; ISBN 0128148543.

41. Turton, R.; Bailie, R.C.; Whiting, W.B.; Shaeiwitz, J.A.; Bhattacharyya, D. Analysis, Synthesis and Design of Chemical Processes, 4th ed.; Turton, R., Ed.; Pearson Education: London, UK, 2008.

42. Reed, T.B. Efficiencies of methanol production from gas, coal, waste or wood. Am. Chem. Soc. Div. Fuel Chem. Prepr. 1976, 21, 2-21.

43. Chen, J.; Yang, S.; Qian, Y. A novel path for carbon-rich resource utilization with lower emission and higher efficiency: An integrated process of coal gasification and coking to methanol production. Energy 2019, 177, 304-318. [CrossRef]

44. Xiang, D.; Li, P.; Yuan, X.; Cui, P.; Huang, W. Highly efficient carbon utilization of coal-to-methanol process integrated with chemical looping hydrogen and air separation technology: Process modeling and parameter optimization. J. Clean. Prod. 2020, 258, 120910. [CrossRef]

45. Zhang, D.; Duan, R.; Li, H.; Yang, Q.; Zhou, H. Optimal design, thermodynamic, cost and $\mathrm{CO}_{2}$ emission analyses of coal-to-methanol process integrated with chemical looping air separation and hydrogen technology. Energy 2020, 203, 117876. [CrossRef] 
46. Yi, Q.; Li, W.; Feng, J.; Xie, K. Carbon cycle in advanced coal chemical engineering. Chem. Soc. Rev. 2015, 44, 5409-5445. [CrossRef]

47. Qin, Z.; Zhai, G.; Wu, X.; Yu, Y.; Zhang, Z. Carbon footprint evaluation of coal-to-methanol chain with the hierarchical attribution management and life cycle assessment. Energy Convers. Manag. 2016, 124, 168-179. [CrossRef]

Publisher's Note: MDPI stays neutral with regard to jurisdictional claims in published maps and institutional affiliations.

(C) 2020 by the authors. Licensee MDPI, Basel, Switzerland. This article is an open access article distributed under the terms and conditions of the Creative Commons Attribution (CC BY) license (http://creativecommons.org/licenses/by/4.0/). 